\title{
Exploring Dietary Practices, Perceptions and Knowledge of Mothers of Toddlers visiting Primary Care Physicians
}

\author{
Khudija Amna Arif, ${ }^{1}$ Hina Jawaid, ${ }^{2}$ Marriam Sheraz, ${ }^{1}$ Zia Ul Hasan, ${ }^{1}$ Babra Naveed, ${ }^{1}$ Hina Akhter ${ }^{1}$
}

\begin{abstract}
Background: Mother is responsible for upbringing of infants and children as she decides their health and food.

Objective: To assess the mother's beliefs and practices related to foods like bananas, dates, rice, eggs, ghee, butter, and factors influencing these practices.

Methodology: A cross-sectional study was conducted between December 2020 and March 2021 among mothers of young children (up to 3 years of age). Responses were collected through interviews. Data were collected from primary health centers (Nainsukh, Gajjumata) and OPD of Fatima Memorial Hospital, Lahore, PHCs Mubarakabad, and Nehranwalaa, district Okara. Questionnaire included information, about the diet given to children such as weaning foods introduced at 6 months and food items consumed by kids up until the age of 3 years. Data were analyzed using SPSS 25.

Results: Out of 333 mothers overall 239 (72\%) mothers fed, carbohydrate rich diet as part of weaning, $81 \%$ of these mothers were educated up to school level $(\mathrm{p}=0.001)$. Bananas were avoided by $100 \%$ of mothers who had no education $(p=0.000)$ due to their perception that their use is linked to increased risk of mucous and chest problems in child. Similarly, eggs were not introduced in children due to misconception that it causes skin rash, fever, or loose stools, with $96 \%$ of mothers with no education, $98 \%$ with school education, and $42 \%$ with higher education $(p=0.000)$. Similar trends were use of dates $(\mathrm{p}=0.00)$, rice $(\mathrm{p}=0.02)$, and butter $(\mathrm{p}=0.002)$ among mothers in the 3 educational groups.
\end{abstract}

Conclusion: Majority of the mothers used a carbohydrate-rich diet as weaning food, and most of these mothers were educated. Majority of the uneducated mothers avoided bananas, eggs, dates, rice, and butter due to misconceptions.

Keywords: Elderly Influence, Maternal Education, Maternal food choice, Weaning food, Misconceptions, Food item.

Article Citation: Arif KA, Jawaid H, Sheraz M, Hasan ZU, Naveed B, Akhter H. Exploring Dietary Practices, Perceptions and Knowledge of Mothers of Toddlers visiting Primary Care Physicians, JSZMC 2021;12(4):13-18. DOI: https://doi.org/10.47883/jszmc.v12i4.181

This Open Access Article in Journal of Sheikh Zayed Medical College is licensed under a Creative Commons Attribution- 4.0 International License(CC BY 4.0).

\section{Introduction}

Malnutrition, a non-communicable disease (NCD) is a pathological state of having deficiencies, excesses, or imbalances in a person's intake of nutrients. An underweight child may be stunted, wasted, or both. ' 'Wasting' is defined as low weight for height whereas 'stunting' refers to low height for age. Children with low weight for age are known as 'underweight'. 'Overweight' and 'obesity' refers to having weight in excess of height, mainly related to intake of high-calorie foods accompanied with negligible physical activity. Such individuals can be malnourished too if the food they are consuming lacks essential nutrients. ${ }^{1}$ The findings of joint child malnutrition estimates (JME) showed 149.2 million children under 5 globally in 2020, were stunted, 59 million were underweight, 45.4 million were wasted and 39 million were over-weight. ${ }^{2}$ Factors affecting the earlier introduction of complementary feed (CF) i.e., before completing 4 months include younger maternal age, mothers' educational level (lower), babies who are never breastfed, preterm babies, and those who received infant formula milk. ${ }^{3}$ Among the number of factors contributing to persistently high rates of stunting in Uganda, one was the lack of introduction of complementary feeding at the appropriate age. ${ }^{4}$ In places where lack of food availability was not an issue suboptimal CF practices particularly in relation to the choice of food items were observed due to poor maternal knowledge. ${ }^{5}$ Global estimates of feeding practices revealed that approximately one-third of infants of

1. Department of Family Medicine, FMH College of Medicine \& Dentistry, Shadman, Lahore, Pakistan.

2. Department Family Medicine, University of Health Sciences Lahore, Pakistan.

Correspondence: Dr. Hina Jawaid, Department of Family Medicine, University of Health Sciences, Lahore, Pakistan.

Email: hinajawaid@uhs.edu.pk

Received: 11-09-2021 Published: 11-12-2021 
age 4-5 months are already fed solid food, whereas $28.2 \%$ children age $6-23$ months receive minimally varied diet. Cultural factors and poor knowledge of the primary caregivers are found to be important determinants of inadequate complementary feeding $(\mathrm{CF})$ in even the richest of households. ${ }^{6}$ If mothers do not have knowledge about a healthy balanced diet or if they perceive healthy food as harmful, they will not incorporate these food items into their child's regular diet even if they are easily available locally. ${ }^{7}$ Various surveys have been conducted in parts of the world to address challenges in managing malnutrition, including anemia which affects $42 \%$ of children under 5 globally. One such study investigated maternal perceptions relating to causes, clinical features, and prevention of anemia identified that a higher maternal knowledge score about childhood anemia was associated with higher maternal educational status and parity. ${ }^{8}$ Wide variation in the timing of the introduction of solids and liquids to infants' diet has been noted across the globe. Despite continuous implementation and promotion of national guidelines on infant feeding in developed countries like Australia, 50\% of mothers who were aware of these recommendations were struggling to start solid foods at around 6months of age, barriers being their perception, peer pressure, conflicting and competing advice from more experienced family members and in presence of above caregiver not sure what weightage to give to the national recommendations. ${ }^{9}$ Likewise, $46 \%$ of mothers in a study from Turkey enrolling 1486 mothers and children aged 12-23 months, started complementary feed before 6 months of age. ${ }^{10}$

Pakistan's demographic and health survey 20122013, from 489 communities showed the introduction of solids, semi-solids, and soft foods were achieved at 6-8months in $67 \%$ of infants where only $22 \%$ aged $6-23$ months were meeting minimum dietary diversity (MDD). Timely introduction of semi-solid food, minimum meal frequency, dietary diversity, and acceptable diet criteria was analyzed it was found that there was inadequate consumption of fresh fruits and vegetables, legumes, and vitamin A rich foods in all age groups. ${ }^{11}$ In the subcontinent there are many misconceptions regarding childcare, these misconceptions are influenced by cultural traditions and beliefs. Mother's education about child care plays an important role in fulfilling the growth requirements of infants and young children. ${ }^{12}$ Nutrition plays a vital role in infants' and young children's mental, physical and cognitive development. This survey aims to know about barriers to maternal and child healthy feeding practices and to know how prevalent food-related myths and beliefs are among young mothers in our population. The misconceptions about some specific foods like eggs, bananas, ghee, and dates result in children being deprived of some highly nutritious and affordable food items. This study was planned to assess the mother's beliefs and practices related to foods like bananas, dates, rice, eggs, ghee, and butter, and the role of factors such as maternal education and the influence of elders affecting these practices.

\section{Methodology}

A cross-sectional study using a questionnaire specially designed for this purpose, in both English and Urdu languages, was used. Preliminary piloting and validation of the questionnaire were carried out to fine-tune the questions and responses. At places where the population was unable to read or write an educated person (locally) identified and trained to assist mothers in responding to questions. The survey was conducted between December 2020 and March 2021 among mothers of young children (up to 3 years of age) following participant's consent (both verbal and written). Responses were collected through face-to-face interviews, phone calls, and via online questionnaire (due to COVID19). Data was collected from these primary and secondary health care centres based in urban and peri-urban settings. Two remote villages were also identified to collect data. Nainsukh PHC under the management of Fatima Memorial Hospital Lahore, Gajjumata PHC running in collaboration with Fatima Memorial Hospital Lahore, Fatima Memorial Hospital OPD, Mubarakabad, Depalpur, Okara, Nehranwala, Depalpur, Okara. As per WHO the recommended age of weaning is 6 months. In terms of education, we classified someone as "uneducated" if he/she has not been to school at all. If someone has attended up to grade 5 in school is considered as having "primary" education, whereas anyone above that, up to $12^{\text {th }}$ grade was considered as having "secondary" education". Those with qualifications from college and universities above $12^{\text {th }}$ standard were classed as "higher".

Questionnaire: The questionnaire was composed of 
4 parts as follows: (1) Socio-demographic characteristics, (2) Mothers feeding practices (3) maternal knowledge relating to the use of certain food items (4) Mothers perception about various foods given to infants and toddlers. The questionnaire included nine practice-related questions, one knowledge-related question, and six perception-related questions. If the participant's responses matched the defined criteria; a score of 1 was given while any other response was given a score of 0 . In response to weaning foods consumed by the child different food groups were arranged together for example carbohydrate-rich foods: cerelac, sago pudding, bread, rice, mashed potatoes, porridge, rusk, biscuits were in one group, fruit and vegetables were in another and protein-rich foods: dal, egg, chicken, minced meat formed the $3^{\text {rd }}$ group. If certain foods from that group were included in the child's diet the score of 1 was given and if not then the score was 0 . If there were elders (grandparents /others) at home advising about child nutrition score was 1 and if not score was 0 .

Different child nutrition-related advice given by the elderly were given different scores e.g. advice to discard the colostrum and not feed it to the baby was scored as 0 ; advice to breastfeed the child was scored as 1; don't feed the child banana in the winter season was scored as 2; advice to feed the child cerelac, rice, porridge, etc was scored as 3; advice not to feed the child eggs in summer season was scored as 4; feed the child cow's milk was scored as 5; advice to start weaning at age lesser than 6 months was scored as 7; feed the child tea plus other miscellaneous advises were scored as 8 . Whereas if the mothers introduced weaning food at age 6 months score was 1 if weaning was delayed beyond 6 months score was 2 and if weaning was started earlier than 6 months then a score of 0 was assigned in SPSS. Questions about specific food items were asked including banana, eggs, rice, dates, butter, and ghee or clarified butter each one was scored separately as; If fed the baby all year round the score was 1 ; If fed it to the baby only in a particular season and avoided rest of the year the score was 0 . Knowledge-related questions were if the mother knew the age of weaning was 6 months? Score 1 for "yes" and 0 for "no". The perception-related questions were included to identify if mothers were avoiding the use of certain foods due to myths attached to them. If the caregiver did not feed the child one of the selected food items due to perception or myth it was scored as 0 and if she was feeding it then a score of 1 was given. A score of 1 was also given if the parent did not have a perception about that food but were unable to add that in the child's diet due to inability to afford it. Perceptions identified were as follows; Bananas cause chest infection, cough, sputum, etc in winters; Eggs cause heat, fever, rash, diarrhea, itching in the summer months; Dates should not be fed to the child because they cause heat, skin rashes in summers; Use of rice can lead to a chest infection in winter months and diarrhea in summers; Use of butter in winter can lead to chest infection; Use of ghee in summers is harmful because it causes heat, allergy, hepatitis and is difficult to digest by a child in winters ghee causes sore throat.

Sample size: The sample size was 333 , calculated based on the confidence interval of $95 \%$, and a sample size calculator called Raosoft was used to calculate the sample size.

Inclusion criteria: Mothers who had one or more children of age 3 years and younger.

Exclusion criteria: Children with cleft palate and cleft lip resulting in difficulty in feeding. Mothers of twins were excluded to eliminate recall bias. Children with health issues needing a special diet were also excluded.

Statistical Analysis: Data were be analyzed by chisquare using SPSS 25.

Ethical consideration: Ethical clearance was obtained from the Institutional Review Board (IRB) of Fatima Memorial Hospital, IRB number FMH-11-2020-IRB-834-M

\section{Results}

A total of 333 mothers with one or more children up to 3 years of age were interviewed. Maternal age ranged from 19-41 years (mean 28 years) whereas ages of children ranged from 4-36 months (mean 14.5 months). Out of the total, $172(52 \%)$ were males and $161(48 \%)$ children were females and $254(76 \%)$ mothers were homemakers while 79 (24\%) were working women. Most fathers were earning; 119 $(36 \%)$ were self-employed, 110 (33\%) were employed, $101(30 \%)$ worked as a laborer or in a factory while a minority were jobless $3(0.9 \%)$. In terms of the level of education of fathers, they were 
broadly categorized into unschooled 64 (19\%), those who had received education up to primary or secondary level 159 (49\%), and those who had higher education 110 (32\%). Similarly, mothers who never attended school 59 (18\%), those who attended primary or secondary school $156(47 \%)$, and mothers who received higher education 118 (35\%). Monthly household incomes income ranges were $\mathrm{Rs}<20,000$ per month in $95(28 \%)$ respondents, those with earnings between Rs. 20,000-49,000 per month 136 (41\%), then those with Rs. 50,000-99,000/month were $29(9 \%)$ while Rs. 100,000 /month and above income households were $73(22 \%)$. Out of the total, 239 $(72 \%)$ of the families owned their homes whereas $94(28 \%)$ lived in rented property. In terms of having personal transport, 228 (69\%) owned one while $105(31 \%)$ used public transport. A total of 123 participants (37\%) were urban dwellers, 194 (58\%) lived in peri-urban settings while $15(5 \%)$ study population were residents of rural areas.

On enquiring if the elders in family had an influence on the dietary intake of the grandchild, $68 \%$ mothers (226) responded 'yes' while 32\% (107) mothers stated no such influence; 68\% (226) mothers stated their decision to select food was influenced by the grandparent, mothers with college or university qualification (81\%) were more influenced compared to those who attend school $(65 \%)$ or were uneducated $49 \%(\mathrm{p}=0.000)$. Of the 226, $154(68 \%)$ mothers knew the accurate age of introducing semisolid food at the recommended age of 6 months $(p=0.02)$. Carbohydrate-rich foods remained commonly consumed weaning food with 239 mothers using it, $70 \%$ in the uneducated class, $81 \%$ of those who attended school, and $60 \%$ of highly qualified ones $(p=0.001)$. Of the 21 mothers who opted for protein-rich weaning foods, $60 \%$ belonged to the educational group that attended college or university $(p=0.7)$. Highly qualified mothers appear

Table-I: Maternal Education, Elderly influence, Common food misconceptions and Practices

\begin{tabular}{|c|c|c|c|c|c|c|c|}
\hline \multirow{2}{*}{\multicolumn{2}{|c|}{ Variables }} & \multicolumn{4}{|c|}{ Maternal education } & \multirow{2}{*}{\multicolumn{2}{|c|}{ P-value }} \\
\hline & & No Edu. & School Edu. & \multicolumn{2}{|c|}{ Coll/Univ deg. } & & \\
\hline \multicolumn{8}{|c|}{ Elderly influence on a child's diet } \\
\hline \multicolumn{2}{|c|}{ Yes $[226 / 333(68 \%)]$} & $29(49 \%)$ & $101(65 \%)$ & \multirow{2}{*}{\multicolumn{2}{|c|}{$\begin{array}{l}96(81 \%) \\
22(19 \%)\end{array}$}} & \multirow{2}{*}{\multicolumn{2}{|c|}{0.000}} \\
\hline \multicolumn{2}{|c|}{ No $[107 / 333(32 \%)]$} & $30(51 \%)$ & $55(35 \%)$ & & & & \\
\hline \multicolumn{8}{|c|}{ Age of introduction of weaning } \\
\hline \multicolumn{2}{|c|}{$=6$ months } & $18(31 \%)$ & $39(25 \%)$ & \multicolumn{2}{|c|}{$33(28 \%)$} & \multirow{3}{*}{\multicolumn{2}{|c|}{0.5}} \\
\hline \multicolumn{2}{|c|}{ At 6 months } & $26(44 \%)$ & $73(47 \%)$ & \multicolumn{2}{|c|}{$44(37 \%)$} & & \\
\hline \multicolumn{2}{|c|}{$>6$ months } & $15(25 \%)$ & $44(28 \%)$ & \multicolumn{2}{|c|}{$41(35 \%)$} & & \\
\hline \multicolumn{8}{|c|}{ Type of weaning food } \\
\hline \multicolumn{2}{|c|}{ Predominantly carbohydrates } & $41(70 \%)$ & $127(81 \%)$ & \multicolumn{2}{|c|}{$71(60 \%)$} & \multicolumn{2}{|c|}{0.001} \\
\hline \multicolumn{2}{|c|}{ Predominantly proteins } & $4(7 \%)$ & $8(5 \%)$ & \multicolumn{2}{|c|}{$9(60 \%)$} & \multicolumn{2}{|c|}{0.7} \\
\hline \multicolumn{2}{|c|}{ Fruits and vegetables } & $21(36 \%)$ & $61(39 \%)$ & \multicolumn{2}{|c|}{$54(46 \%)$} & \multicolumn{2}{|c|}{0.35} \\
\hline \multicolumn{2}{|c|}{ Tea/biscuits } & $0(0 \%)$ & $8(5 \%)$ & \multicolumn{2}{|c|}{$4(3 \%)$} & \multicolumn{2}{|c|}{0.19} \\
\hline \multicolumn{8}{|c|}{ Specific food items not used by caregivers and reasons given by them } \\
\hline $\begin{array}{l}\text { Food } \\
\text { item }\end{array}$ & Reason & & $\begin{array}{c}\text { No } \\
\text { education }\end{array}$ & $\begin{array}{c}\text { School } \\
\text { education }\end{array}$ & $\begin{array}{r}\text { Coll } \\
\text { ve } \\
\text { d }\end{array}$ & & $\begin{array}{c}\text { P- } \\
\text { value }\end{array}$ \\
\hline Banana & $\begin{array}{l}\text { Increased risk of che } \\
\text { mucous formation in wi }\end{array}$ & n, cough, and & $25(100 \%)$ & $73(94 \%)$ & $26(7$ & & 0.000 \\
\hline & lack of availability or af & & $0(0 \%)$ & $5(6 \%)$ & $8(24$ & & \\
\hline & Rash, fever, loose motic & nmers & $23(96 \%)$ & $43(98 \%)$ & $11(4$ & & 0000 \\
\hline Eggs & Lack of availability or a & & $1(4 \%)$ & $1(2 \%)$ & $15(5$ & & 0.000 \\
\hline Dates & $\begin{array}{l}\text { Rash, fever in summer/1 } \\
\text { young child }\end{array}$ & ble food for a & $13(93 \%)$ & $11(39 \%)$ & $12(2$ & & 0.000 \\
\hline & Lack of availability or a & & $1(7 \%)$ & $17(61 \%)$ & $39(7$ & & \\
\hline Rice & $\begin{array}{l}\text { Chest infection in winte } \\
\text { summers }\end{array}$ & otions & $6(100 \%)$ & $8(100 \%)$ & $1(50$ & & 0.02 \\
\hline & Lack of availability or a & & $0(0 \%)$ & $0(0 \%)$ & $1(50$ & & \\
\hline Ghee & $\begin{array}{l}\text { Fever, skin rash, and jau } \\
\text { infection in winters }\end{array}$ & ummers/chest & $6(55 \%)$ & $15(75 \%)$ & $12(7$ & & 0.5 \\
\hline & Lack of availability or a & & $5(46 \%)$ & $5(25 \%)$ & $5(29$ & & \\
\hline Butter & Chest infection/expecto & winters & $10(67 \%)$ & $16(59 \%)$ & $3(15$ & & \\
\hline Dutter & Lack of availability or & ility & $5(33 \%)$ & $11(41 \%)$ & $17(8$ & & 0.002 \\
\hline
\end{tabular}


to use more fruits and vegetables at 6months compared to their peers $(46 \%, \mathrm{p}=0.35)$ as seen in table-I.

On exploring reasons for not using certain food items, bananas were avoided by caregivers mainly due to the risk of the child having mucous and chest problems, such misconceptions were seen predominantly in mothers who received no education or had school education only $(100 \%$, 94\%) compared to those with college or university degree $(77 \%)(p=0.000)$ table-I. Similarly, eggs were not introduced in infants or older child's food due to the risk of developing skin rash, fever, or loose stools by $93 \%$ and $98 \%$ of mothers who had no education at all or attended school education in contrast to $42 \%$ mothers who attended higher education $(\mathrm{p}=0.000)$. Almost identical patterns were observed in all three educational classes of mothers in the use of dates $(p=0.00)$, rice $(p=0.02)$, and butter $(p=0.002)$. It was interesting to note that with the exception of ghee, food affordability as the reason for not including food items in child diet was a

Table II: Use of six Food items all year round by Mothers of various Educational Status

\begin{tabular}{|c|c|c|c|c|c|}
\hline \multicolumn{6}{|c|}{ Specific food items used all year round } \\
\hline Food item & $\begin{array}{c}\text { Elderly } \\
\text { influence }\end{array}$ & $\begin{array}{c}\text { Mothers with no } \\
\text { education }\end{array}$ & $\begin{array}{c}\text { Mothers with } \\
\text { School education } \\
\text { only }\end{array}$ & $\begin{array}{c}\text { Mothers with } \\
\text { College/University } \\
\text { degree }\end{array}$ & P-value \\
\hline Bananas & $\begin{array}{l}\text { Yes } \\
\text { No }\end{array}$ & $\begin{array}{l}30(51 \%) \\
29(49 \%)\end{array}$ & $\begin{array}{l}77(49 \%) \\
79(51 \%)\end{array}$ & $\begin{array}{l}81(69 \%) \\
37(31 \%)\end{array}$ & 0.004 \\
\hline Eggs & $\begin{array}{l}\text { Yes } \\
\text { No }\end{array}$ & $\begin{array}{l}22(37 \%) \\
37(63 \%)\end{array}$ & $\begin{array}{c}101(65 \%) \\
55(35 \%)\end{array}$ & $\begin{array}{l}90(76 \%) \\
28(24 \%)\end{array}$ & 0.000 \\
\hline Dates & $\begin{array}{l}\text { Yes } \\
\text { No }\end{array}$ & $\begin{array}{l}38(64 \%) \\
21(36 \%)\end{array}$ & $\begin{array}{l}110(71 \%) \\
46(30 \%)\end{array}$ & $\begin{array}{l}65(55 \%) \\
53(45 \%)\end{array}$ & 0.03 \\
\hline Rice & $\begin{array}{l}\text { Yes } \\
\text { No }\end{array}$ & $\begin{array}{l}46(78 \%) \\
13(22 \%)\end{array}$ & $\begin{array}{c}140(90 \%) \\
16(10 \%)\end{array}$ & $\begin{array}{c}111(94 \%) \\
7(6 \%)\end{array}$ & 0.005 \\
\hline Butter & $\begin{array}{l}\text { Yes } \\
\text { No }\end{array}$ & $\begin{array}{l}35(59 \%) \\
24(41 \%) \\
\end{array}$ & $\begin{array}{l}117(75 \%) \\
39(25 \%) \\
\end{array}$ & $\begin{array}{l}92(78 \%) \\
26(22 \%) \\
\end{array}$ & 0.024 \\
\hline Ghee & $\begin{array}{l}\text { Yes } \\
\text { No }\end{array}$ & $\begin{array}{l}41(70 \%) \\
18(30 \%)\end{array}$ & $\begin{array}{l}125(80 \%) \\
31(20 \%)\end{array}$ & $\begin{array}{l}93(79 \%) \\
25(21 \%)\end{array}$ & 0.23 \\
\hline
\end{tabular}

Table III: Elderly Influence on Parent's Food Choice for their Children

\begin{tabular}{|c|c|c|c|}
\hline \multicolumn{4}{|c|}{ Elders influencing children's food intake } \\
\hline & Yes & No & P-value \\
\hline Elderly influence & $226(68 \%)$ & $107(32 \%)$ & \\
\hline \multicolumn{4}{|l|}{ Age of weaning } \\
\hline$<6$ months & $57(25 \%)$ & $33(31 \%)$ & \multirow{3}{*}{0.5} \\
\hline 6 months & $101(45 \%)$ & $42(39 \%)$ & \\
\hline$>6$ months & $68(30 \%)$ & $32(30 \%)$ & \\
\hline \multicolumn{4}{|c|}{ Mothers' knowledge of correct age of weaning } \\
\hline & $154(68 \%)$ & $72(32 \%)$ & 0.02 \\
\hline \multicolumn{4}{|l|}{ Choice of weaning food } \\
\hline Tea Biscuits & $10(4 \%)$ & $216(96 \%)$ & 0.24 \\
\hline Predominantly carbs & $168(74 \%)$ & $58(26 \%)$ & 0.13 \\
\hline Predominantly proteins & $14(6 \%)$ & $212(94 \%)$ & 0.9 \\
\hline Fruits and vegetables & $87(39 \%)$ & $139(62 \%)$ & 0.2 \\
\hline \multicolumn{4}{|c|}{ Specific food items used all year round } \\
\hline Bananas & $138(61 \%)$ & $88(39 \%)$ & 0.01 \\
\hline Eggs & $144(64 \%)$ & $82(36 \%)$ & 0.89 \\
\hline Dates & $131(58 \%)$ & $95(42)$ & 0.001 \\
\hline Rice & $198(88 \%)$ & $28(12 \%)$ & 0.18 \\
\hline Butter & $166(74 \%)$ & $60(26 \%)$ & 0.9 \\
\hline Ghee & $174(77 \%)$ & $52(23 \%)$ & 0.6 \\
\hline
\end{tabular}




\begin{tabular}{|c|c|c|c|c|}
\hline \multicolumn{5}{|c|}{ Specific food items not used by caregivers all year round } \\
\hline & Reason & $\begin{array}{l}\text { Elderly influence } \\
\text { present }\end{array}$ & $\begin{array}{l}\text { No elderly } \\
\text { influence }\end{array}$ & P-value \\
\hline \multirow{2}{*}{ Banana } & $\begin{array}{l}\text { Increased chest infection, cough, and mucous } \\
\text { formation in winters }\end{array}$ & $73(86 \%)$ & $52(98 \%)$ & \multirow{2}{*}{0.017} \\
\hline & $\begin{array}{l}\text { Lack of availability or } \\
\text { affordability }\end{array}$ & $12(14 \%)$ & $1(2 \%)$ & \\
\hline \multirow[b]{2}{*}{ Eggs } & Rash, fever, loose motions in summers & $50(77 \%)$ & $29(94 \%)$ & \multirow[b]{2}{*}{0.046} \\
\hline & $\begin{array}{l}\text { Lack of availability or } \\
\text { affordability }\end{array}$ & $15(23 \%)$ & $2(6 \%)$ & \\
\hline \multirow{2}{*}{ Dates } & $\begin{array}{l}\text { Rash, fever in summer/ } \\
\text { Not suitable food for a young child }\end{array}$ & $26(35 \%)$ & $10(56 \%)$ & \multirow{2}{*}{0.1} \\
\hline & $\begin{array}{l}\text { Lack of availability or } \\
\text { affordability }\end{array}$ & $49(65 \%)$ & $49(65 \%)$ & \\
\hline \multirow[b]{2}{*}{ Rice } & Chest infection in winters/ lose motions in summers & $12(92 \%)$ & $3(100 \%)$ & \multirow[b]{2}{*}{0.6} \\
\hline & $\begin{array}{l}\text { Lack of availability or } \\
\text { affordability }\end{array}$ & $1(8 \%)$ & $0(0 \%)$ & \\
\hline \multirow{2}{*}{ Ghee } & $\begin{array}{l}\text { Fever, skin rash, and jaundice in summers /chest } \\
\text { infection in winters }\end{array}$ & $23(68 \%)$ & $10(71 \%)$ & \multirow{2}{*}{0.79} \\
\hline & $\begin{array}{l}\text { Lack of availability or } \\
\text { affordability }\end{array}$ & $11(32 \%)$ & $4(29 \%)$ & \\
\hline \multirow[b]{2}{*}{ Butter } & Chest infection /expectoration in winters & $18(43 \%)$ & $11(55 \%)$ & \multirow[b]{2}{*}{0.3} \\
\hline & $\begin{array}{l}\text { Lack of availability or } \\
\text { affordability }\end{array}$ & $24(57 \%)$ & $9(45 \%)$ & \\
\hline
\end{tabular}

concern mainly raised by mothers with higher education compared to their counterparts. Consumption of bananas, eggs, rice, and butter all year round, was noted more among children belonging to mothers with higher qualifications (banana $\mathrm{p}=0.004$, eggs $\mathrm{p}=0.000$, rice $\mathrm{p}=0.005$, butter $\mathrm{p}=0.024$ ) (Table-II) compared to their fellows. It was identified that bananas and dates were included in the child's diet all year round where the mother's choice was affected by older members of the family. $(p=0.01 \& 0.001$ respectively) (Table-III).

\section{Discussion}

Two-third of our respondents reported the choice of food for their kids was affected by grandparents or other elders in the house. These findings are similar to one from rural Baluchistan ${ }^{13}$ in pointing out that the aged members of the family are considered as an authority in the choice of food for their grand-child regardless of what is considered nutritionally healthy for the child. We identified inadequate utilization of food resources due to lack of knowledge or because of misbelief despite the fact that parents had access to foodstuffs and were able to afford it too. The introduction of complementary feed was either early or late in $57 \%$ of cases in our study, the type of weaning food was predominantly carbohydrates in $72 \%$ whereas fruits and vegetables were used by $41 \%$ of mothers. Deficient use of ironrich foods was observed. Although studies have shown that higher levels of maternal education are associated with reduced undernutrition in young children, an argument that informal education on health and nutrition can also help those mothers who are unable to receive higher education, to gain knowledge which in turn improves practices. ${ }^{14}$ Furthermore, higher maternal education led to a better understanding of pediatric anemia, which affects more than half of pre-school children in developing countries. ${ }^{15}$ Community-based interventions to promote maternal health education can be cost-effective and can be used long term. Even in underprivileged areas, with a high ratio of poverty and malnutrition, a structured communitybased intervention in areas of food economics, healthy diet, and food safety can have successful outcome. ${ }^{16}$ Maternal education during the antenatal period in rural Bangladesh led to minimal improvement in timely initiation of $\mathrm{CF}$ indicating factors other than maternal knowledge play a role in timely introduction of solids and liquids. ${ }^{17}$ Evaluation of complementary feeding practices in a study from Abu Dhabi revealed more consumption of sugar-rich foods, was attributed to poor maternal knowledge rather than availability of food. ${ }^{18}$ Keeping in view these observations, it may be prudent to focus on improving the household's 
nutritional knowledge including elderly members of the family rather than solely focusing on caregivers. Baby-led weaning, a concept already well-established in the west can be considered as a way to start solids in infants' diet. The baby-led weaning approach is useful for making infants independent using the self-feeding process ${ }^{19}$ it is also associated with higher levels of confidence in giving complementary feed by mothers. ${ }^{20}$ Information on nutritional advantages of foods like banana, eggs, rice, dates, ghee, and butter must be introduced to mothers which will, in turn, promote inclusion of these items in infants and toddlers' diets. The Islamic Republic of Pakistan is among the countries in the world with the highest rates of child malnutrition (stunting 38\% wasting 15\% and underweight $31 \%$ ) and its progress in child nutrition and health remained slower than in other South Asian countries. ${ }^{21}$ The survey was not only used as a tool to collect information but also for the education of mothers, a unique feature of this study, a follow-up of the same cohort in 3-6 months can reveal changes in mothers' knowledge gap and perceptions.

\section{Conclusion}

This study showed that the majority of the mothers used a carbohydrate-rich diet as weaning food, and most of these mothers were educated. The majority of the uneducated mothers avoided bananas, eggs, dates, rice, and butter due to misconceptions.

Authors Contribution: KAA: Conception of work, Acquisition and analysis of data and Revising. HJ: Design of work, Interpretation of data and Drafting. MS: Design of work and drafting. ZUH: Acquisition and analysis of data and revising. BN: Conception of work and drafting. HA: Design of work and drafting.

All authors critically revised and approve its final version.

Conflict of Interest: Author has declared no conflict of interest.

Sources of Funding: The source of funding was self.

Declaration: None

\section{References}

1. World Health Organization. Malnutrition [Internet]. Who.int. World Health Organization: WHO; 2020. Available from: https:/www.who.int/news-room/factsheets/detail/malnutrition.

2. The UNICEF/WHO/WB Joint Child Malnutrition Estimates (JME) group released new data for 2021 [Internet]. www.who.int. Available from: https://www.who.int/news/item/06-05-2021-the-unicefwho-wb-joint-child-malnutrition-estimates-groupreleased-new-data-for-2021.

3. Zielinska, Rust, Masztalerz-Kozubek, Bichler, Hamułka. Factors Influencing the Age of Complementary Feeding-A Cross-Sectional Study from Two European Countries. International Journal of Environmental Research and Public Health. 2019 Oct 9;16(20):3799.

4. Bukusuba J, Kaaya AN, Atukwase A. Predictors of Stunting in Children Aged 6 to 59 Months: A Case-Control Study in Southwest Uganda. Food and Nutrition Bulletin [Internet]. 2017 Dec 1;38(4):542-53. Available from: https://pubmed.ncbi.nlm.nih.gov/28978233

5. Taha Z, Garemo M, Nanda J. Complementary feeding practices among infants and young children in Abu Dhabi, United Arab Emirates. BMC Public Health. 2020 Aug 27;20(1).

6. White JM, Bégin F, Kumapley R, Murray C, Krasevec J. Complementary feeding practices: Current global and regional estimates. Maternal \& Child Nutrition. 2017 Oct;13:e12505.

7. Hirvonen K, Hoddinott J, Minten B, Stifel D. Children's Diets, Nutrition Knowledge, and Access to Markets. World Development. 2017 Jul;95:303-15.

8. World Health Organization. World Health Organization [Internet]. Who.int. World Health Organization; 2020. Available from: https://www.who.int

9. Begley A, Ringrose K, Giglia R, Scott J. Mothers' Understanding of Infant Feeding Guidelines and Their Associated Practices: A Qualitative Analysis. International Journal of Environmental Research and Public Health. 2019 Mar 29;16(7):1141.

10. Complementary Feeding Practices of Children Aged 1223 Months in Turkey. Central European Journal of Public Health. 2015 Jun;23(2):149-54.

11. Na M, Aguayo VM, Arimond M, Stewart CP. Risk factors of poor complementary feeding practices in Pakistani children aged 6-23 months: A multilevel analysis of the Demographic and Health Survey 2012-2013. Maternal \& Child Nutrition. 2017 Oct;13:e12463.

12. Hasan MT, Soares Magalhaes RJ, Williams GM, Mamun AA. The role of maternal education in the 15-year trajectory of malnutrition in children under 5 years of age in Bangladesh. Maternal \& Child Nutrition. 2015 Feb 26;12(4):929-39 
13. Baloch FA, Jogezai NA, Mohamad Ismail SAM. Food and Cultural Norms: Rural Mothers' Selection of Nutrition Intake for Their Young Children. Health Education [Internet]. 2020;120(1):87-106. Available from: https://eric.ed.gov/?id=EJ1255544

14. Fadare O, Amare M, Mavrotas G, Akerele D, Ogunniyi A. Mother's nutrition-related knowledge and child nutrition outcomes: Empirical evidence from Nigeria. Vellakkal S, editor. PLOS ONE [Internet]. 2019 Feb $28 ; 14(2)$ : e 0212775 . Available from: https://www.ncbi.nlm.nih.gov/pmc/articles/PMC639492 2/

15. World Health Organisation. Anaemia [Internet]. www.who.int. 2020 . Available from: https://www.who.int/health-topics/anaemia\#tab=tab_1

16. Salem M, Yousof H, Abdelmoneim O. Improvement of Healthy Diet Related Knowledge among a Sample of Egyptian Women in Three Upper Egypt Governorates Using a Community Based Intervention. Open Access Macedonian Journal of Medical Sciences. 2019 Aug 30;7(17):2947-52.

17. Owais A, Suchdev PS, Schwartz B, Kleinbaum DG, Faruque ASG, Das SK, et al. Maternal knowledge and attitudes towards complementary feeding in relation to timing of its initiation in rural Bangladesh. BMC Nutrition. 2019 Jan 30;5(1).
18. Taha Z, Garemo M, Nanda J. Complementary feeding practices among infants and young children in Abu Dhabi, United Arab Emirates. BMC Public Health. 2020 Aug 27;20(1):37-39

19. Chickpeas for Babies - First Foods for Baby [Internet]. $\mathrm{S}$ ol id Starts. Ava i l a b 1 e from: https://solidstarts.com/foods/chickpea/

20. Brown A, Lee M. A descriptive study investigating the use and nature of baby-led weaning in a UK sample of mothers. Maternal \& Child Nutrition. 2010 Dec 10;7(1):34-47.

21. Tackling malnutrition in South Asia: 8 Years on [Internet]. blogs.worldbank.org. Available from: https://blogs.worldbank.org/endpovertyinsouthasia/tackl ing-malnutrition-south-asia-8-years 